\title{
Congenital dyserythropoietic anaemia with erythroblastic multinuclearity
}

\author{
MALCOLM BRIGHT, JEREMY COBB, BYRON EVANS, AND T. E. PARRY1 \\ From the Departments of Medicine and Clinical Pathology, Llandough Hospital Penarth, Glamorgan
}

SYNOPSIS A case of congenital dyserythropoietic anaemia with erythroblastic multinuclearity in a 36-year-old woman is described and the literature reviewed. The syndrome is characterized by a protracted clinical course, a relatively mild anaemia, a low reticulocyte count, slight hyperbilirubinaemia, splenomegaly, pronounced erythroid hyperplasia with reversal of the myeloid erythroid ratio, and in particular by the presence of multinucleated erythroblasts in the marrow. The picture of ineffective erythropoiesis is confirmed by erythrokinetic studies. The present case is the fortyfirst to be described in the literature and is the third from Britain. Thirty-one of these have occurred in seven families but a family history has been lacking in the remaining ten. The onset of anaemia occurred in childhood in 21 of the 41 cases.

\section{Case Report}

A housewife born in 1936 had no symptoms of note until she was admitted to hospital with rheumatic fever at the age of 16 years. A harsh systolic murmur was noticed over the precordium and the spleen was palpable. The haemoglobin was $10 \cdot 1 \mathrm{~g}$ on admission and $13.0 \mathrm{~g}$ on discharge, and the bilirubin varied between 0.6 and $1.2 \mathrm{mg} \%$, but two days after discharge she became clinically jaundiced for the first time.

She has had four children, born in 1956, 1957, 1959 , and 1960 . The splenomegaly was present during each pregnancy, the splenic tip being $7.5 \mathrm{~cm}$ below the left costal margin. The haemoglobin varied between $9.5 \mathrm{~g}$ and $11.9 \mathrm{~g}$ during the first three pregnancies. She was admitted to another hospital during the thirty-eighth week of her fourth pregnancy with a haemoglobin of $5.5 \mathrm{~g}$. The peripheral blood film showed marked anisocytosis, poikilocytosis, macrocytosis, and polychromasia. Some hypochromic microcytic cells were present as well. The sternal marrow was reported as 'a cellular marrow showing transitional megaloblastic hyperplasia'. Unfortunately we have been unable to trace these films. Serum $B_{12}$ was $125 \mu \mathrm{g} / \mathrm{ml}$ but the serum folate was not determined. A diagnosis of macrocytic anaemia of pregnancy was made and she was transfused with

${ }^{1}$ Requests for reprints should be sent to DrT. E. Parry, Department of Clinical Pathology, Llandough Hospital, Penarth, Glamorgan Received for publication 8 March 1972.
5 units of compatible concentrated cells followed by oral folic acid therapy. The reticulocytes did not rise above $1.5 \%$ during the next 12 days but the haemoglobin rose to $10.8 \mathrm{~g}$ during the puerperium, and it varied between $8.4 \mathrm{~g}$ and $10.6 \mathrm{~g}$ during the next 10 months. The patient was sterilized in 1961 .

From 1966 to 1970 she had had intermittent abdominal pain, mainly in the left hypochondrium which was attributable to the enlarged spleen. Her other symptoms have been lethargy, slight weight loss, slight dyspnoea on exertion, and occasional palpitations. Her haematological findings during this period ranged as follows: haemoglobin from $9.4 \mathrm{~g}$ to $12.3 \mathrm{~g}$, the MCV from 83 to $100 \mathrm{c} \mu$, the MCHC from 28 to $36 \%$, the leucocytes from 3700 to 12800 , reticulocytes from 1.0 to $4.3 \%$, and the platelets from 98000 to 220000 per cmm. The red cell fragility had been slightly raised and the neutrophil alkaline phosphatase score was 8 per 100 neutrophils. Haemoglobin electrophoresis showed haemoglobin A only.

On examination in June 1970 there was no clinical anaemia, jaundice, or lymphadenopathy. The spleen was enlarged and tender, its lower border reaching almost to the umbilicus. The liver and kidney were not palpable nor were any other abdominal masses felt. Since then her clinical condition has remained unchanged and at the time of writing (January 1972) her haemoglobin is $12.2 \mathrm{~g}$, RBCs $3.63 \times 10^{6}, \mathrm{MCV} 92 \mathrm{c} \mu$, MCHC $36 \%$, and the WBC $5200 / \mathrm{cmm}$. 


\section{Marrow Appearances}

Two sternal marrow biopsies were done, the first in June 1970 and the second in May 1971. The first marrow was exceedingly cellular and showed a pronounced degree of erythroblastic hyperplasia with a myeloid/erythroid ratio of $1 / 2 \cdot 9$. Erythropoiesis was predominantly normoblastic and macronormoblastic in type but a number of nucleated red cells showed definite megaloblastic change. The most striking feature, however, was the presence of multinucleated erythroblasts, 108 of which were encountered in counting 1000 nucleated red cells. The majority contained two nuclei but cells containing three, four, and even six nuclei were encountered. Of these $66 \%$ were in late, 29.5 in intermediate, and 4.5 in early erythroblasts. The late erythroblasts in addition showed both nuclear lobulation and nuclear fragmentation (karyorrhexis). Myelopoiesis was active and appeared normal but

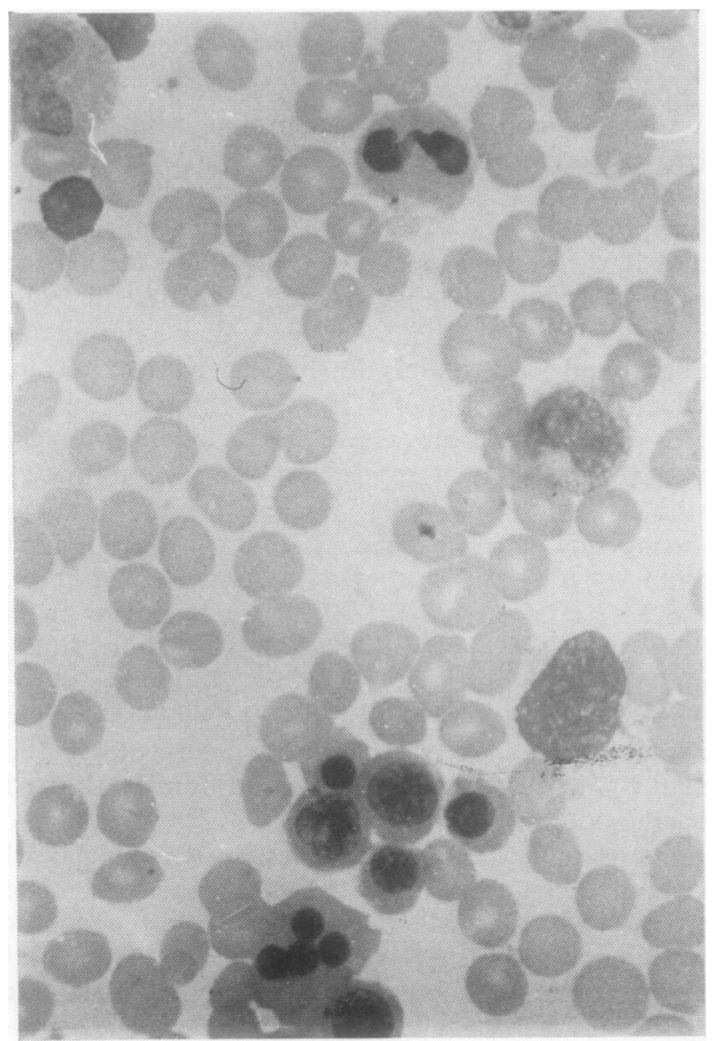

Fig. 1a. 'ghost' cells were prominent. Megakariocytes were numerous. Iron stores in the marrow were slightly increased but ringed sideroblasts were not seen. The second marrow, with 101 multinucleated red cell/1000 erythroblasts, showed all the features present in the first including the very occasional erythroblast which showed definite megaloblastic change (Fig. 1a), although the serum $\mathbf{B}_{12}$ and folate levels at the time of the biopsy were $165 \mu \mu \mathrm{g}$ and $8.7 \mathrm{ng} / \mathrm{ml}$ respectively. In addition this marrow showed $(a)$ internuclear chromatin bridges, which were not numerous, only two were encountered in counting 1000 erythroblasts, but several other examples were encountered on more extensive is examination of the films (Fig. 1a, b, c, and d), and were not seen on re-examination of the first marrow; ir (b) abnormal mitoses (Fig. 1e); and (c) abnormal $\stackrel{9}{9}$ erythroblasts in which the nuclei consisted of $\frac{\text { 의 }}{4}$ amorphous masses of chromatin which lacked any recognizable morphological pattern. These cells could

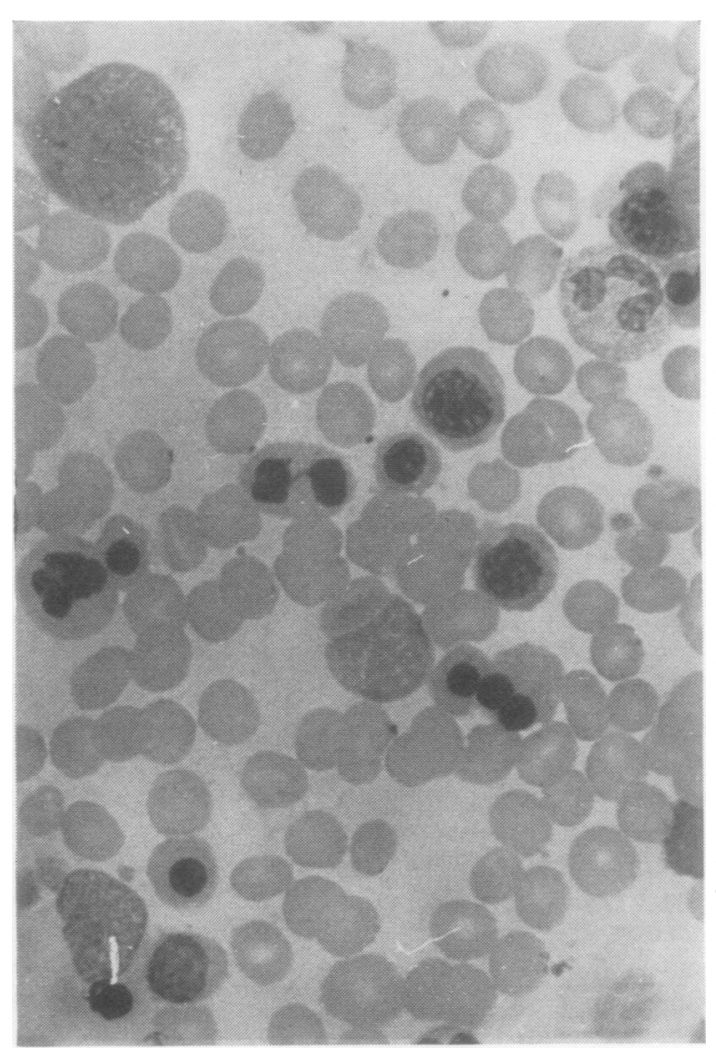

Fig. 1b.

Fig. 1a Erythrocyte with internuclear chromatin bridge (top); Multinucleated cell at the bottom together with three erythroblasts showing megaloblastic change.

Fig. 1b Internuclear bridging. 


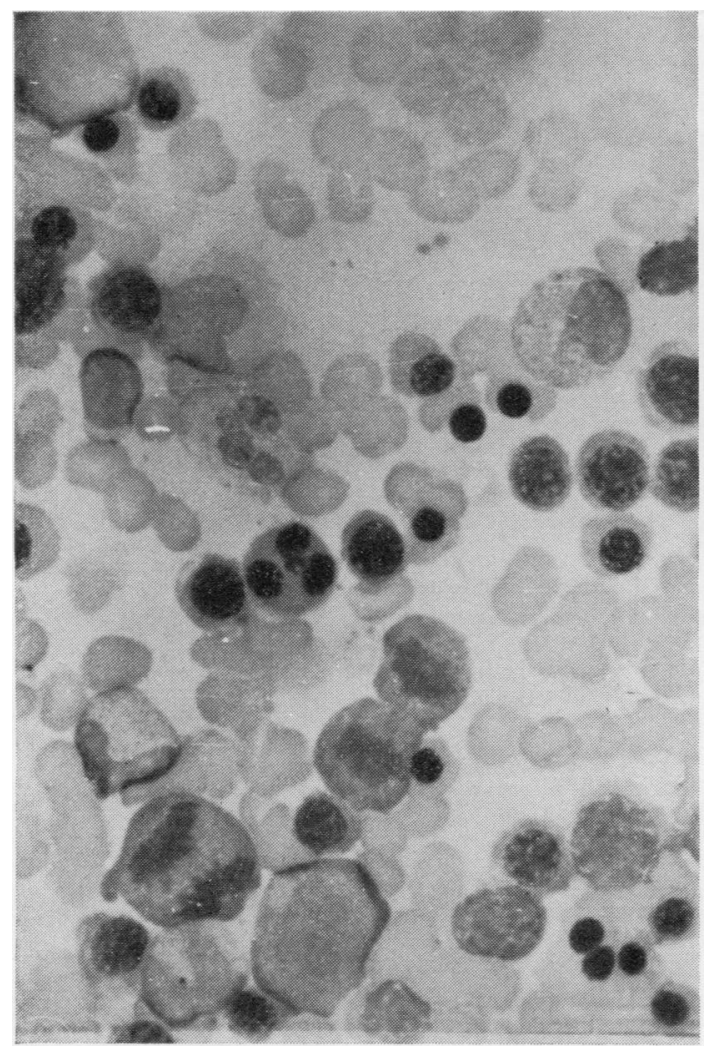

Fig. 1c.

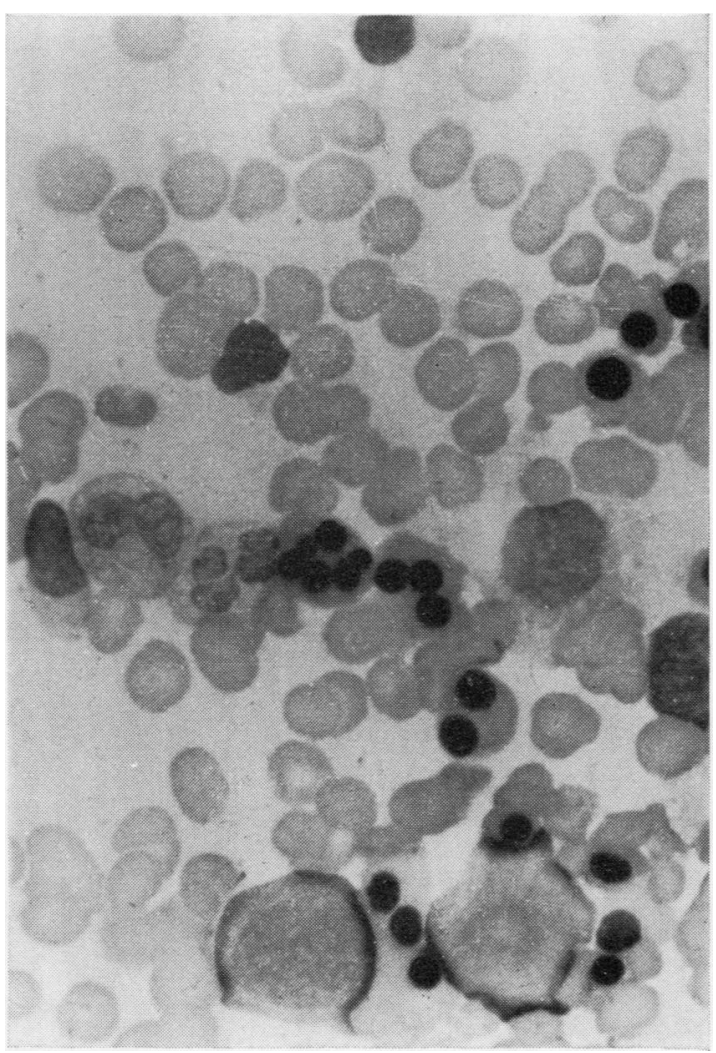

Fig. 1d.

Fig. 1c Erythrocyte with three nuclei, two of which are joined by a chromatin bridge.

Fig. 1d Erythrocytes with multiple nuclei. One cell contains six nuclei, two of which are joined by a slender chromatin bridge.

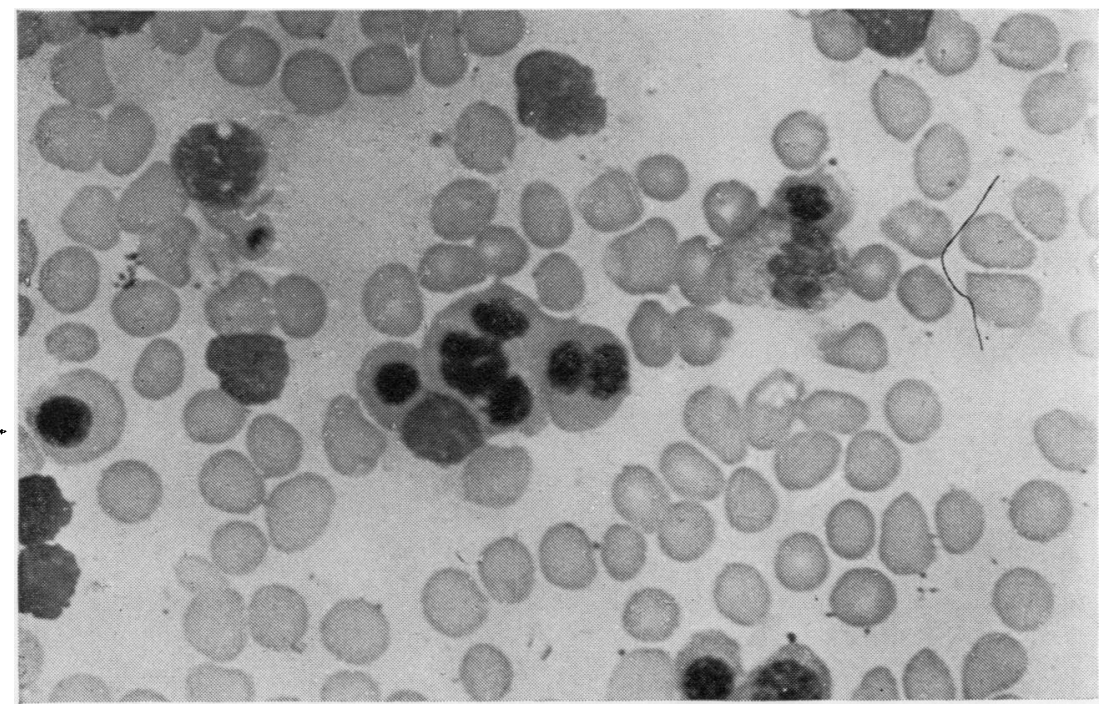

Fig. 1e Erythrocyte showing abnormal mitosis. 
Case

No.

Author Nomenclature No. of

Case in

Family History

Sex Age at

Diagnosis

(yr)

Age at
Onset

Onset of

(yr)

Reticu-

locytes

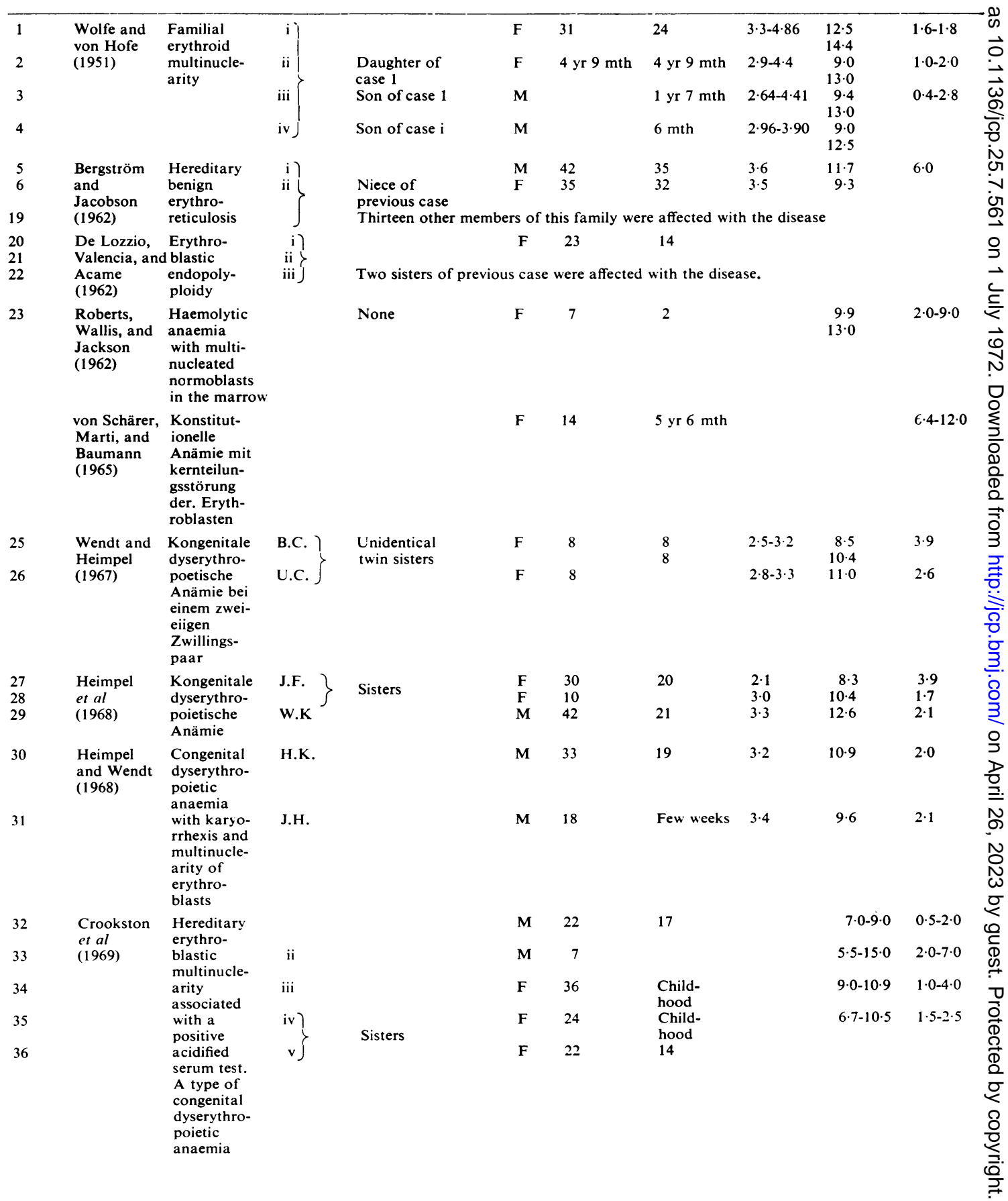




\begin{tabular}{|c|c|c|c|c|c|c|c|c|c|c|}
\hline \multirow{3}{*}{$\begin{array}{l}W B C \\
\times 10^{3}\end{array}$} & \multirow{3}{*}{$\begin{array}{l}\text { Platelets } \\
\times 10^{3}\end{array}$} & \multirow{3}{*}{ Film } & \multirow{3}{*}{$\begin{array}{l}\text { Percentage } \\
\text { of Erythro- } \\
\text { blasts } \\
\text { with More } \\
\text { than One } \\
\text { Nucleus }\end{array}$} & \multirow{3}{*}{$\begin{array}{l}\text { Serum } \\
\text { Iron } \\
\mu \mathrm{g} / \\
100 \mathrm{ml}\end{array}$} & \multirow{3}{*}{$\begin{array}{l}\text { Total } \\
\text { Iron- } \\
\text { binding } \\
\text { Capacity }\end{array}$} & \multicolumn{5}{|c|}{ Erythrokinetics } \\
\hline & & & & & & ${ }^{{ }^{1} \mathrm{Cr}}$ & $\begin{array}{l}\text { Plasma } \\
\text { Fe } \\
\text { Clear- } \\
\text { ance } \\
\left(T \_ \text {min }\right)\end{array}$ & $\begin{array}{l}\text { Plasma } \\
\text { Fe } \\
\text { Turnover }\end{array}$ & $\begin{array}{l}\text { Fe } \\
\text { Utiliza- } \\
\text { tion at } \\
10 \text { Days }\end{array}$ & Type \\
\hline & & & & & & $(N>26)$ & $\begin{array}{l}(N=60 \\
120)\end{array}$ & & $(N>70 \%$ & \\
\hline $4 \cdot 0-6 \cdot 5$ & $30 \cdot 0-257 \cdot 0$ & & 19 & & & & & & & III \\
\hline $5 \cdot 0-15 \cdot 95$ & $281 \cdot 0$ & & 16 & & & & & & & III \\
\hline \multirow[t]{2}{*}{$5 \cdot 0-19 \cdot 65$} & $224 \cdot 0$ & & & & & & & & & III \\
\hline & & & 13 & & & & & & & III \\
\hline \multirow[t]{4}{*}{$\begin{array}{l}8 \cdot 4 \\
5 \cdot 5\end{array}$} & $\begin{array}{l}142 \cdot 0 \\
231 \cdot 0\end{array}$ & $\begin{array}{l}\text { Anisocytosis } \\
\text { Anisocytosis }\end{array}$ & & $\begin{array}{l}160 \\
169\end{array}$ & & 20 & & & & $\begin{array}{l}\text { III } \\
\text { III }\end{array}$ \\
\hline & & Anisocytosis & $9 \cdot 9$ & & & & & & & $\begin{array}{l}\text { III } \\
\text { III }\end{array}$ \\
\hline & & & $\begin{array}{l}\text { Not } \\
\text { stated }\end{array}$ & & & Normal & & & & II \\
\hline & & $\begin{array}{l}\text { Anisocytosis } \\
\text { and } \\
\text { poikil- } \\
\text { ocytosis }\end{array}$ & $28 \cdot 5$ & & & 31 & 98 & Increased & & II \\
\hline $2 \cdot 8$ & $240 \cdot 0$ & & & & & 22 & 26 & $+t+$ & 15 & I \\
\hline $3 \cdot 1$ & 180.0 & & & & & 20 & 25 & ++ & 30 & I \\
\hline
\end{tabular}

$13 \cdot 2 \quad 670 \cdot 0$

$9 \cdot 3 \quad 430 \cdot 0$

6.0230

Micro-

$\begin{array}{ll}17 \cdot 7 & 230\end{array}$

250

18

40

$++$

16

$\mathbf{I}$

Cytosis

chromatosis

$8.4530-0$

Micro-

$18 \cdot 5$

220

240

19

50

$+$

23

II

Hypo-

chromatosis

$\begin{array}{lr}5 \cdot 0-9 \cdot 0 & \begin{array}{rr}160 \cdot 0 \\ 250 \cdot 0\end{array} \\ 3 \cdot 0-25 \cdot 0 & 59 \cdot 0 \\ & 320 \cdot 0 \\ 7 \cdot 0-13 \cdot 0 & 200 \cdot 0 \\ & 230 \cdot 0 \\ 8 \cdot 5-9.5 & 580\end{array}$

$\begin{array}{llllllll} & 186 & 320 & 22 & 22 & ++ & 18 & \text { II } \\ 22 & & & & & & \\ 32 & 108 & 278 & 25 & 48 & ++ & 26 & \\ 32 & & 21 & & & \text { II } \\ 20 & & & & 30 & 35 & \text { II }\end{array}$




\begin{tabular}{|c|c|c|c|c|c|c|c|c|c|c|}
\hline $\begin{array}{l}\text { Case } \\
\text { No. }\end{array}$ & Author & Nomenclature & $\begin{array}{l}\text { No. of } \\
\text { Case in } \\
\text { Series }\end{array}$ & Family History & Sex & $\begin{array}{l}\text { Age at } \\
\text { Diagnosis } \\
(y r)\end{array}$ & $\begin{array}{l}\text { Age at } \\
\text { Onset of } \\
\text { Anaemia } \\
(y r)\end{array}$ & $\begin{array}{l}R B C \\
\times 10^{6}\end{array}$ & $H b$ & $\begin{array}{l}\text { Reticu- } \\
\text { locytes }\end{array}$ \\
\hline
\end{tabular}

\begin{tabular}{|c|c|c|c|c|c|c|c|c|c|c|}
\hline 37 & Verweil- & Ineffective & i) & Two sisters & $\mathbf{M}$ & 25 & 7 & $3 \cdot 94$ & $13 \cdot 8$ & $1 \cdot 6$ \\
\hline 38 & $\begin{array}{l}\text { gen et al } \\
\text { (1969) }\end{array}$ & $\begin{array}{l}\text { erythropoi- } \\
\text { esis with }\end{array}$ & ii $\}$ & $\begin{array}{l}\text { and one } \\
\text { brother }\end{array}$ & $\mathbf{M}$ & 23 & $\begin{array}{l}\text { Child- } \\
\text { hood }\end{array}$ & $3 \cdot 97$ & $13 \cdot 4$ & $1 \cdot 6$ \\
\hline 39 & & morphologic- & iii & & $\mathbf{F}$ & 22 & 13 & 3.92 & $13 \cdot 8$ & $1 \cdot 2$ \\
\hline 40 & & $\begin{array}{l}\text { ally abnor- } \\
\text { mal erythro- } \\
\text { blasts and } \\
\text { unconjug- } \\
\text { ated hyper- } \\
\text { bilirubin- } \\
\text { aemia }\end{array}$ & iv & & $\mathbf{M}$ & 13 & $\begin{array}{l}\text { From } \\
\text { birth }\end{array}$ & $1 \cdot 35$ & $6 \cdot 7$ & $3 \cdot 4$ \\
\hline 41 & $\begin{array}{l}\text { Present } \\
\text { case }\end{array}$ & $\begin{array}{l}\text { Congenital } \\
\text { dyserythro- } \\
\text { poietic } \\
\text { anaemia with } \\
\text { erythro- } \\
\text { blastic } \\
\text { multinucle- } \\
\text { a rity }\end{array}$ & & & $\mathrm{F}$ & 34 & 16 & $2 \cdot 76-4 \cdot 04$ & $5 \cdot 5 \cdot 13 \cdot 0$ & $1 \cdot 0-4 \cdot 3$ \\
\hline
\end{tabular}

Table Summary of cases reported in the literature

not be described either as normoblasts or megaloblasts and appeared in some instances at least to arise as the result of the abnormal mitosis.

Chromosome analysis of the peripheral blood on two occasions showed a normal karyotype. Unfortunately insufficient mitoses were present in the marrow cultures on each occasion for chromosome analysis.

\section{Biochemical Findings}

The following biochemical values have been obtained at various times. The serum bilirubin varied from normal to a maximum of $2.5 \mathrm{mg} \%, 52 \%$ of which was indirect; blood urea $29 \mathrm{mg} \%$; uric acid $4.6 \mathrm{mg} \%$; serum albumin $4.7 \mathrm{~g} \%$, globulin $2.9 \mathrm{~g} \%$; immunoglobulin (mg/100 ml), IgG 1100 and 1800 (normal 600-1 600), IgA 238 and 250 (normal 125-480), IgM 95 and 82 (normal 50-200); serum iron 95 and $65 \mu \mathrm{g} / 100 \mathrm{ml}$. Total iron-binding capacity was 270 and $285 \mu \mathrm{g} / 100 \mathrm{ml}$. Serum $B_{12}$ was 160 and $165 \mu \mu \mathrm{g} / \mathrm{ml}$, serum folate 3.2 and $8.7 \mathrm{ng} / \mathrm{ml}$. The 24-hour excretion of urobilinogen was $0.32 \mathrm{mg}$ (normal up to $1.0 \mathrm{mg}$ ), and the 24-hour excretion of faecal sterobilinogen was $378 \mathrm{mg}$ (normal 50$300 \mathrm{mg}$ ). The red cell glucose phosphate dehydrogenase was $4.4 \mathrm{Iu} / \mathrm{g}, \mathrm{Hb}$ (normal 5-10), and the red cell pyruvate kinase $196 \mathrm{~m} \mu / 10^{9} \mathrm{RBC}$ (normal 60-220).

\section{Serological Findings}

The acidified serum (Ham) test was positive on several occasions when the patient's cells were tested against acidified normal compatible serum but negative against her own serum. The sucroselysis test (Dacie and Lewis, 1968) and the DonathLandsteiner tests were both negative. Her blood belonged to group $\mathrm{B} \mathrm{Rh}+$ of genotype $\mathrm{cDE} / \mathrm{cde}$, $\mathrm{Pl}+$. The direct antiglobulin (Coombs) test was repeatedly negative. Irregular antibodies were not detected when tested in saline, albumin with papain or by the Coombs test, neither were the patient's cells haemolysed when tested against anti-B or anti-O hightitre sera, nor were they lysed after being in contact with her own serum for 24 hours. Tests for platelet antibodies and for leucocyte agglutinins were likewise negative.

The I i status was investigated by $\mathrm{Dr}$ W. J. Jenkins of the North East Metropolitan Regional Blood Transfusion Centre. Her serum contained a weak anti-I, active in saline at $4{ }^{\circ} \mathrm{C}$ but not at room temperature. Her cells had high normal agglutınation scores against anti-I but higher than normal scores against anti-i. They were also unduly susceptible to lysis by anti-I and to a lesser extent by anti-i. 


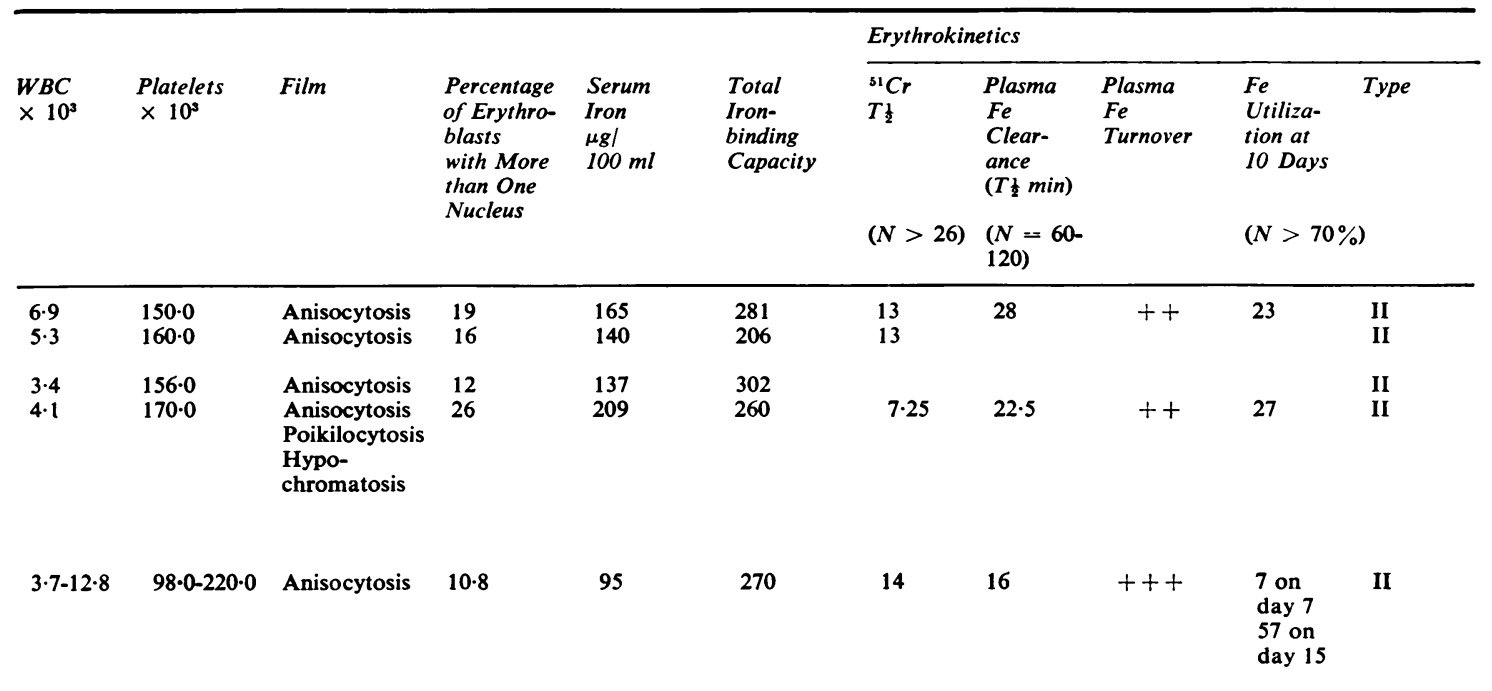

\section{Erythrokinetics}

The red cell survival was reduced, the ${ }^{51} \mathrm{Cr} \mathrm{T}$ being 14 days (normal 25-32 days), but counts over the spleen and liver after 24 hours and seven days did not indicate excessive splenic sequestration. Ferrokinetic studies showed a rapid plasma iron clearance with the ${ }^{59} \mathrm{Fe} \mathrm{T}_{\frac{1}{2}}$ of 16 minutes (normal $60-120$ minutes). The plasma iron turnover was 2.75 $\mathrm{mg} / 100 \mathrm{ml}$ of blood/24 hours (normal $0 \cdot 74-1 \cdot 3$ $\mathrm{mg} / 100 \mathrm{ml}$ blood $/ 24$ hours) and the red cell utilization was considerably reduced with $7 \%$ utilization on the seventh day and $57 \%$ on the fifteenth day (normal $>70 \%$ at 10 days).

\section{Family History}

Both parents are alive, but divorced. Both have remarried, and each has children from the second marriage. Full blood counts (including platelet and reticulocyte), absolute values, the examination of peripheral films, and the Ham test were done on the patient's father and mother, her three sons and one daughter, her only sister, and three half sisters. Of the latter, two have the same mother and the other has the same father as the patient. All the results were essentially normal.

\section{Discussion}

The condition was first described by Wolff and von Hofe (1951) as a familial erythroid multinuclearity which affected a mother and three of her children. Thirty-six further cases have since been described in 15 families. These are summarized in the Table. Thirty-one of the $\mathbf{4 0}$ cases have occurred in seven families. The present case, therefore, is the fortyfirst to be described and the third to be reported from Britain, the previous two were those of Roberts, Wallis, and Jackson (1962) and case 2 of Crookston, Crookston, Burnie, Francombe, Dacie, Davis, and Lewis (1969). It is noteworthy that the onset of the anaemia occurred in childhood in 21 of the 41 cases.

Chromosome analysis of marrow has shown polyploidy with more than 60 chromosomes in the same percentage of cells as have multiple nuclei (De Lozzio, Valencia, and Acame, 1962) but chromosome analysis of blood has usually yielded normal results.

The congenital dyserythropoeitic anaemias have been divided into three types on the basis of the marrow appearances (Heimpel and Wendt, 1968; Heimpel, Wendt, Klemm, Schubothe, and Heilmeyer, 1968): type I, those showing megaloblastic 
changes with internuclear bridges and macrocytosis; type II, those showing bi- and multinuclearity, pleuripolar mitosis, karyorrhexis, and normocytosis; and type III, those showing pronounced multinuclearity with up to 12 nuclei in a cell, gigantoblasts, and macrocytosis.

Crookston et al (1969) have further divided them into two groups on a genetic basis, namely, those showing a dominant and those showing a recessive inheritance. The same authors reported a positive acidified serum (Ham) test, a negative sugar water test, a high agglutination score with anti-i, and an increased susceptibility to lysis by both anti-I and anti-i in their five cases, including two sisters.

We have not been able to find evidence of a similar disorder in the patient's family but in view of the similarity of our case with others in the literature we consider this case to be an example of recessive inheritance of the disorder. Although megaloblastic change and internuclear bridging were both present in the marrow they were much less conspicuous than in the type I cases of Heimpel and Wendt where they are encountered in 75 and $5 \%$ of erythroblasts respectively. Karyorrhexis and abnormal mitoses were, however, more prominent in the present case. In a recent communication Dr S. M. Lewis ${ }^{1}$ described a case in which internuclear bridging was prominent but the Ham test was negative. He considers positive acid serum lysis as characteristic of type II of Heimpel and Wendt and we consider that the present case also belongs to this type.

The ineffective erythropoiesis leads to iron overloading (Heimpel and Wendt, 1968; Crookston et al, 1969). Iron therapy is therefore contraindicated and blood transfusions should be given only in emergencies. The anaemia is usually of a mild degree and the course of the present case supports the view of Crookston et al (1969) that the anaemia does not become more severe with the passage of time.

The positive acid haemolysis test suggests a significant abnormality in the red cell membrane (Crookston et al, 1969); (Verwilghen, Verhaegen, Waumans, and Beert, 1969). The same defect might also be reflected by the increased anti-i agglutination score. The latter, however, reflects a reversion to a foetal cell characteristic and appears to be a nonspecific phenomenon which has been encountered in other states of severe proliferative erythropoietic stress (Dr W. J. Jenkins, personal communication).

The salient feature of the disorder, the erythroblastic multinuclearity, has been considered the

${ }^{1}$ Lewis, S. M., Pitcher, C. S., and Nelson, D. A communication presented at a recent (Jan. 1972) meeting of the British Society for Haematology. result of normal karyokinesis ie, nuclear division, with suppression of cytokinesis (Wolff and von Hofe, 1951; Bergström and Jacobsson, 1962). Although this might account for the gigantoblast described by these authors in cases which belong to type III we agree with Heimpel and Wendt (1968) that this is an unlikely explanation for the karyorrhexis and abnormal mitosis encountered in type II cases. These features, as well as the megaloblastic change and internuclear bridging observed in type I cases and shown to a minor degree in the present case, provide strong evidence that nuclear division is in fact impaired in cases belonging to both these types.

We wish to thank Dr Beryl Bevan, Dr W. J. Jenkins, and Dr K. L. G. Goldsmith for assistance with the serological investigations, Professor Alan Jacobs and Dr M. Beamish for the erythrokinetic studies, Mr R. A. Saunders for the biochemical investigations, Dr K. M. Laurence for the chromosome analysis, Dr F. K. Storring for translating the German literature, and Mr Graham Haddock for the photographs.

\section{References}

Bergström, I., and Jacobsson, L. (1962). Hereditary benign erythroreticulosis. Blood, 19, 296-303.

Crookston, J. H., Crookston, M. C., Burnie, L. K. Francombe, W. H., Dacie, J. V., Davis, J. A., and Lewis, S. M. (1969) Hereditary erythroblastic multinuclearity associated with a positive acidified serum test: a type of congenital dyserythropoietic anaemia. Brit. J. Haemat., 17, 11-26.

Dacie, J. V., and Lewis, S. M. (1968). Practical Haematology, 4th ed., p. 186. Churchill, London.

De Lozzio, C. B., Valencia, J. I., and Acame, E. (1962). Chromosoma study in erythroblastic endopolyploidy. Lancet, 1, 1004-1005.

Heimpel, H., Wendt, F., Klemm, D., Schubothe, H., and Heilmeyer, L. (1968). Kongenitale dyserythropoietische Anämie. Arch klin. Med., 215, 174-194.

Heimpel, H., and Wendt, F. (1968). Congenital dyserythropoietic anemia with karyorrhexis and multinuclearity of erythroblasts. Helv. med. Acta, 34, 103-115.

Roberts, P. D., Wallis, P. G., and Jackson, A. D. M. (1962). Haemolytic anaemia with multinucleated normoblasts in the marrow. Lancet, 1, 1186-1187.

Schärer, K., Marti, H. R., and Baumann, T. (1965). Konstitutionelle Anämie nıit Kernteilungsstörung de Erythroblasten. Schweiz. med. Wschr., 44, 1511-1515.

Verwilghen, R., Verhaegen, H., Waumans, P., and Beert, J. (1969) Ineffective erythropoiesis with morphologically abnorma erythroblasts and unconjugated hyperbilirubinaemia. Brit. J. Haemat., 17, 27-33.

Wendt, Von F., and Heimpel, H., (1967). Kongenitale dyserythropoetische Anämie bei einem zweieiigen zwillingspaar. Med. Klin., 62, 172-177.

Wolff, A., and Hofe, F. H. von (1951). Familial erythroid multinuclearity. Blood, 6, 1274-1283.

\section{Addendum}

Since the manuscript was submitted the patient has been subjected to splenectomy (on 1 June 1972) mainly because of the pain and discomfort attributed to the enlarged spleen. A liver biopsy was taken at the operation. 
The spleen weighed $1045 \mathrm{~g}$. There was a well marked area of perisplenitis measuring $12 \times 9 \mathrm{~cm}$ at one pole. The cut surface was dark red with considerable blurring of the normal surface markings and an accentuated degree of trabeculation. There was no evidence of either recent or old infarction.

\section{H IS TOLOGY}

The Malpighian follicles were somewhat smaller than normal, the sinuses were dilated and although a number were empty the great majority were engorged. These appearances were extreme in places with flattening of the sinus endothelium and impaction of the sinuses with red cells, and were consistent with some degree of 'hypersplenism'. Small foci of haemopoietic cells were scattered throughout the pulp and a number of unequivocal late haemoglobinized erythroblasts containing two nuclei were observed (Fig. 2). Only minimal amounts of haemosiderin were present, which were almost entirely confined to the endothelium of veins.

The liver biopsy was pyramidal in shape and measured $2.0 \times 1.5 \times 1.5 \mathrm{~cm}$. It was yellowish and presented a slightly granular appearance.

\section{H ISTOLOGY}

The liver architecture was intact but there was a slight but definite degree of portal fibrosis which was accompanied by a round cell infiltration of the portal tracts. The liver cells appeared normal and there was no evidence of extramedullary erythropoiesis. Only a very occasional haemosiderin granule was seen in section stained with the Perls's reaction.

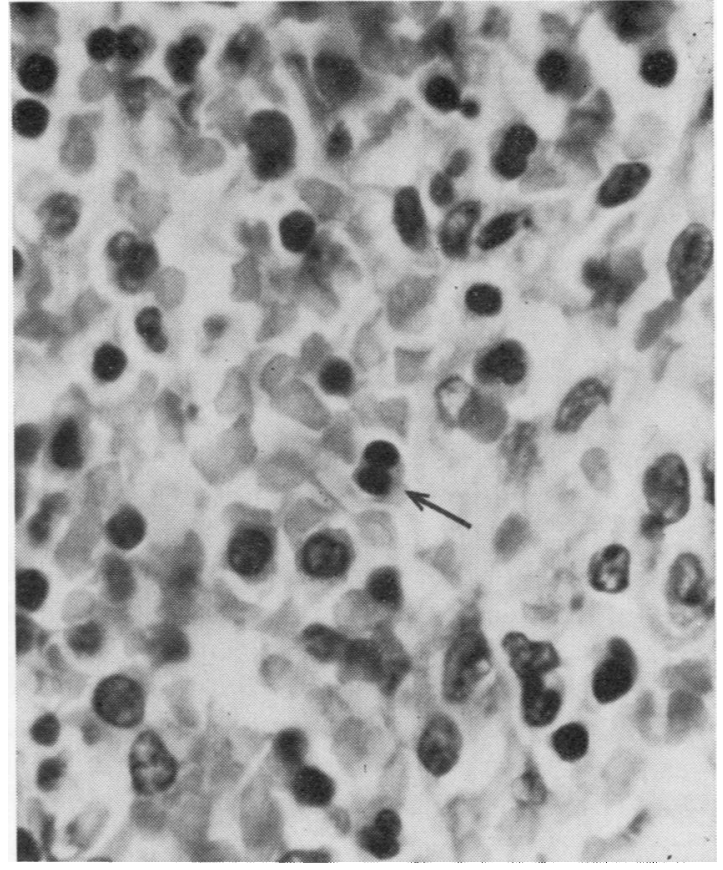

Fig. 2. Bi-nucleated late erythroblast in the spleen.

\section{COMMENT}

The appearances were consistent with some degree of 'hypersplenism'. Extramedullary erythropoiesis was present in the spleen but evidence of iron overloading was lacking. 